\title{
A epistemologia narrativa e o exercício clínico do diagnóstico
}

\author{
The narrative epistemology \\ and the clinical diagnosis practice
}

Maria Helena Cabral de Almeida Cardoso 1

Kenneth Rochel de Camargo Jr. ${ }^{2}$

Juan Clinton Llerena Jr. 1

${ }^{1}$ Centro de Genética Médica José Carlos Cabral de Almeida, Departamento de Genética, Instituto Fernandes Figueira/ Fiocruz. Av. Rui Barbosa 716, Flamengo, 22250-020 Rio de Janeiro RJ. oscarmc@unisys.com.br 2 Instituto de Medicina Social,Universidade Estadual do Rio de Janeiro. kenneth@ueri.br
Abstract This study aims to discuss the narrative epistemology contained in the medical practice. It was based upon a bibliographic review and a semiotic analysis of medical charts belonging to The Medical Genetic Center José Carlos Cabral de Almeida/Genetic Department/Fernandes Figueira Institute, a maternal-infant care unity of The Oswaldo Cruz Foundation. All the analysed charts referred to children diagnosed with Down syndrome that are being or were attended in the Down's Syndrome Outpatient of the above cited unity. The article appraises: the question concerning the possible opposition between narrative and science; a review of multiple authors and their works about narrative and medical knowledge; the narrative epistemology contained in the clinical discourse, using as example of such assumption one chart and one pedigree. The conclusion highlights how narrative is important to the process of diagnosis and treatment, and affirms the construction of a plot, by the physician, where biological, social and cultural interactions make themselves present.

Key words Medicine, Narrative, Medical discourse, Down syndrome
Resumo Este trabalho objetiva contribuir para a discussão acerca das características narrativas do discurso clínico. Para tanto parte de uma revisão bibliográfica e da análise semiótica de prontuários do Centro de Genética Médica José Carlos Cabral de Almeida, do Departamento de Genética, do Instituto Fernandes Figueira, unidade materno-infantil da Fundação Oswaldo Cruz. Todos os prontuários utilizados são referentes a portadores da sindrome de Down atendidos no Ambulatório Especializado de Sindrome de Down da referida unidade. O artigo aborda: a questão da possivel oposição entre narrativa e ciência; a apresentação dos principais autores e de seus trabalhos que versam sobre narrativa e conhecimento médico; a exemplificação da epistemologia narrativa embutida no discurso médico, via a apresentação de um prontuário, assim como de um heredograma. A conclusão enfatiza a importância da narrativa para o processo de diagnose e tratamento, assim como a construção de um enredo por parte do médico onde se fazem presentes complexas interações biológicas, culturais e sociais.

Palavras-chave Medicina, Narrativa, Discurso médico, Síndrome de Down 


\section{Introdução}

O presente artigo tem por objetivo contribuir para a discussão do recurso à narrativa como constituinte do saber científico, ao contrário do que o cientificismo positivista, embora bastante atacado ainda extremamente influente, propugna. Pretende-se, mais especificamente, focar a medicina, partindo-se para tanto de uma abordagem teórica que a articula à história, dentro de um modelo comum de conhecimento, que foi "batizado" por Carlo Ginzburg (1989; 1991) como "indiciário". Não se trata aqui de levantar tal proposição e debatê-la, o que já foi feito em trabalho anterior (Cardoso, 2000), mas de recortar as questões pertinentes à narração, dentro do espaço do adoecimento, recorrendo para tal a uma revisão bibliográfica de autores que se debruçam sobre o tema, assim como à pesquisa em fontes primárias - prontuários de pacientes atendidos no Ambulatório de Síndrome de Down, do Centro de Genética Médica José Carlos Cabral de Almeida, do Departamento de Genética do Instituto Fernandes Figueira, unidade dedicada à pesquisa, ensino e assistência materno-infantil da Fundação Oswaldo Cruz. Cabe também salientar que o trabalho vincula-se a uma linha de pesquisa voltada para o estudo dos discursos médico e leigo sobre adoecimento por uma condição geneticamente determinada.

De início aborda-se epistemologicamente a questão da narrativa no discurso médico; em seguida operacionaliza-se uma leitura semiótica de símbolos e diagramas utilizados pelo discurso médico na construção da diagnose e da evolução da doença do paciente; após intentase uma síntese da produção mais recente sobre as chamadas "narrativas de doença" e, à guisa de conclusão, recupera-se a articulação entre medicina e história, tomando a narrativa como elemento característico dos dois tipos de conhecimento, mostrando a ilusão de se fazer sinonímia entre narrativa e ficção e oposição entre o fabular e o criar cientificamente.

\section{A narratividade}

No que diz respeito à medicina, o diagnóstico que, no dizer de Robert Hooper, em seu tratado Vade-Mecum de 1809, pode ser definido como a arte de transformar sintomas em sinais acabou significando correlacionar a observação ao pé do leito com as revelações que a moderna tecnologia médica oferece e manifestações subjeti- vas com lesões objetivas. E, também implicou a transformação da maneira pessoal de dar conta do sofrimento, num discurso médico profissional que transcodifica o subjetivismo incoerente num texto interpretável. Mas, essa conversão da investigação semiológica, que se traduz no raciocínio diagnóstico, não pode prescindir da narrativa histórica do paciente e de sua doença (Epstein, 1995).

A problemática da relação da explanação histórica com os mecanismos explanatórios na ciência, uma questão importante para a história clínica que cada médico produz sobre seu paciente, faz emergir reflexões que, notadamente, nas décadas após a Segunda Guerra, têm sido sistematizadas por pensadores dos mais diversos campos do conhecimento. Uma delas, por exemplo, é a do entendimento de que os corpos humanos são portadores não só de agentes patogênicos como também de histórias que explicam suas vidas. A necessidade de se construir essas histórias/narrativas sublinha os modos pelos quais as noções de saúde e doença são culturalmente produzidas. Todo ser humano, porque dotado de historicidade, participa de uma coletividade que não pode ser entendida sem suas concepções de mundo, apolítica e/ou afastada das contingências históricas dos sistemas sociais e de crenças.

De acordo com Paul Ricoeur (1988), a historicidade e a narratividade possuem uma relação simbiótica e a história é um discurso de bases narrativas, pois fundamenta-se num enredo que é traçado e até determinado pelo historiador. Todo entendimento histórico, portanto, de acordo com essa ótica, compreende uma concepção de narrativa. O exercício do diagnóstico clínico, ancorando-se na história clínica do paciente cujo um dos objetivos é estreitar a margem de possibilidades das desordens, mediante um rígido relato que vai das primeiras impressões às hipóteses diagnósticas, contém uma epistemologia narrativa nos seus esforços para encapsular tipos específicos de conhecimento acerca do corpo (Epstein, 1995). A anamnese, o relato de caso, e o conjunto de informações que compõem a história clínica não só exigem a transformação das queixas dos pacientes em um texto clínico, mas também a produção de uma explanação diagnóstica que requer funções interpretativas.

Uma multidão de significados pode ser encontrada nos arquivos médicos. As histórias médicas dos pacientes, em suas múltiplas formas, revelam aspectos culturais que organizam, 
institucionalizam e controlam não só os cuidados com a saúde, como a própria maneira como se estruturam as especialidades médicas e as habilidades dos profissionais médicos em lidar com o sofrimento de seus pacientes. Revelam também seus conceitos sobre as doenças e de que forma constróem a narrativa, isto é, como assumem sua historicidade, e que consciência histórica possuem do mundo e de si.

A narração expositora do diagnóstico e da terapêutica, por sua vez, reverbera sobre a constituição da narrativa histórica que cada doente faz dos males que o acometem e entrelaçam-se na rede de intrigas que compõe a verdadeira história.

Por outro lado, se a medicina defronta-se com o sofrimento, a história também. Todavia, a interação das duas raramente tem sido cotejada, quer por médicos, quer por historiadores. Caso se escolha a coletânea mais conhecida sobre a história das doenças (Le Goff, 1991) vê-se que somente um ensaio (Moulin, 1991) oferece uma interpretação, baseada em Foucault, que realiza uma discussão de conteúdo, imbricando técnica médica com atitude crítica/analítica e articulando-as à percepção que os atores sociais contemporâneos têm dos progressos na área biomédica e de produção de fármacos.

Um historiador como Roy Porter, por exemplo, que há anos vem se dedicando à história da medicina, sempre faz relações entre ela, as doenças e os médicos, traçando um painel geral sobre o desenrolar do exercício clínico. Sua preocupação é com a longa duração e com as modificações engendradas ao longo de um continuum evolutivo. O enredamento da medicina com a história dá-se pela transformação da primeira em objeto da segunda, justificado pela visão da medicina como a ciência mais beneficente ao gênero humano. A sua capacidade de transformação da própria natureza da vida dá-se tendo como pano de fundo os credos religiosos, científicos, filosóficos e políticos da cultura de cada época o que, evidentemente, coloca a produção desse autor nos cânones da chamada "história social”, intentando uma abrangência total. Combinando uma enorme erudição com o uso de um número abundante de fontes, Porter (1997) faz uma história épica e ao mesmo tempo crítica da medicina, mas não trabalha qualquer relação intrínseca possível entre ela e a disciplina da história.

Seu argumento central é de que a medicina ocidental desenvolveu maneiras próprias de abordar as formas como os corpos humanos trabalham na saúde e na doença. Tais abordagens mudaram a visão cultural que se faz do corpo na vida humana. A maioria dos povos e culturas em todo o mundo, através da história, construiu a vida - nascimento e morte, doença e saúde -, primeiramente no contexto de entender as relações entre homem e cosmos: planetas, estrelas, montanhas, rios, espíritos ancestrais, deuses e demônios, céu e inferno... O pensamento ocidental moderno, todavia, tornou-se indiferente a todos esses elementos, desenvolvendo uma cultura preocupada com o eu ( self), com o indivíduo e sua identidade e esta conquista culminou por ser equiparada ou reduzida ao corpo individual e à personalidade encarnada, que, por sua vez, expressa-se através da linguagem do corpo.

Porter trabalha muito bem a noção de episteme, tal como desenvolvida por Foucault, realizando uma arqueologia do saber e uma genealogia do poder, contudo sempre exercitando sua condição de historiador. $\mathrm{O}$ arco enciclopédico da obra, na qual a análise reflexiva imbrica-se com uma periodicidade muito bem recortada, faz da empreitada deste professor inglês de história social da medicina, talvez, a melhor história sobre ela produzida recentemente. Trata-se de uma grande narrativa essencialmente histórica sobre a luta do homem contra as enfermidades que acometem seu corpo, discutindo o fato de que nós transformamos médicos em heróis, no entanto nos sentimos ambíguos em relação a eles (Porter, 1997). A narração é a essência da sua obra, por isso ele não a discute, simplesmente a faz.

Já o estudo da forma narrativa dos casos médicos tem em Julia Epstein (1995) e Kathyrn Montgomery Hunter (1991) dois expoentes. A primeira, preocupada com questões teóricas, freqüentemente se reporta à produção historiográfica de Thomas Laqueur e de Roy Porter, assim como à abordagem conceitual de Foucault $\mathrm{e}$ Ricoeur; o foco de sua análise são o corpo e as questões referentes às ambigüidades de gênero. A segunda trabalha com a noção de a medicina não poder se constituir como ciência, diante da individualidade e particularidade com as quais se depara em seu exercício.

Epstein (1995), desenvolve seu trabalho pensando uma analogia entre o corpo biológico e o corpo político, no contexto de desintegração política, étnica, de fronteiras nacionais e de sistemas de governo que ocorre na atualidade. Para ela, as noções de identidade, história e razão, tão associadas ao pensamento do iluminis- 
mo europeu, deram lugar a novos tipos de desordem, inseguranças e incertezas e, concomitantemente, a novas asserções de fronteiras identificatórias.

A atomização das pessoas em identidades étnicas em conflitos, segundo ela, emparelha-se à fragmentação do sistema de assistência médica à saúde em frias "linhas de produção", da profissão médica em subespecialidades e do corpo humano em sistemas de órgãos. Ao invés de mover-se no sentido de uma compreensão mais unificada de psyche e soma, a organização superespecializada dos profissionais médicos trabalha na direção oposta. Entretanto não é a defesa de um "idealismo holístico" que impulsiona o trabalho de Epstein, mas a necessidade epistemológica de mostrar as influências culturais na linguagem médica e de como as concepções por ela veiculadas pressionam as ideologias sociais, estabelecendo uma certeza acerca de uma definição objetiva do que é "normal" no que tange ao corpo humano.

Nesse sentido, ela centra-se nas histórias médicas que os clínicos fazem de seus pacientes, para mostrar que elas, tanto quanto as etnográficas, ficcionais ou históricas surgem por determinadas razões e exigem práticas interpretativas. Embora o corpo humano possa ser descrito como um conjunto de órgãos, fluidos e processos fisiológicos, ele é mais que isso, devendo, no seu entender, ser estudado como uma superfície cultural sobre a qual se mapearam expectativas sociais e significados ideológicos.

Para Epstein, os relatos de casos médicos operacionalizam as características convencionais dos escritos históricos e literários, isto é, da narrativa. Em conseqüência, ela afirma que o sucesso ou fracasso do relato clínico, na qualidade de uma descrição oficial da etiologia e evolução da doença, constitui um paradigma geral para as narrativas sobre o corpo humano. Porém, eles não podem e nem devem ser lidos como uma descrição analítica, porque sempre implicitamente interpretam no processo de sua estrutura narrativa. Ao verter a experiência do doente num texto clínico, o médico também tem que interpretar esta experiência a fim de produzir uma explanação da diagnose, assim como persuadir seus leitores de que o diagnóstico está correto na base não só da evidência, mas também do apelo retórico: as maneiras pelas quais as rupturas na experiência foram incluídas e em quais reconstruções construiu-se um quadro clínico cujos mistérios foram resolvidos (Epstein, 1995). É importante sinalizar, diz ela, que so- mente doenças diagnosticadas, que são plenamente compreendidas na sua progressão fisiológica, operam desta maneira, isto é, tomam um rumo esperado, só que, às vezes, este rumo é modificado por um caso individual.

Ela conclui, numa espécie de retorno ao ponto de partida, sublinhando que é o medo do contágio pelo "Outro" que, hoje, todos temem. E esse temor atiça o fogo repressivo das linguagens do corpo e aquelas, do corpo político. A analogia se restabelece e o círculo se fecha.

Hunter (1991), por sua vez, toma como ponto de partida para seu trabalho, a articulação entre literatura e medicina. Sua ênfase recai sobre a característica eminentemente hermenêutica embutida na construção do saber médico, via a similitude do que chama de "círculo diagnóstico" com o "círculo hermenêutico" proposto por Dilthey (Hunter, 1991). Seu "Sherlock-médico", poder-se-ia dizer, deveria ser um hermeneuta.

Para Hunter, indiscutivelmente, medicina não é uma ciência, mas, sim, uma atividade racional, utilizadora da ciência, situada entre diversos níveis disciplinares, e interpretativa. Por isso, segundo ela, para explicar o que é a medicina e melhor definir sua racionalidade, a literatura fornece uma analogia metodológica mais frutífera do que as ciências naturais e sociais. Porque não só a metáfora da leitura utilizada para a interpretação do estado do doente é uma metáfora literária, mas, sobretudo, porque a medicina já possui algo em comum com a literatura e os estudos literários: o uso da linguagem figurativa e da organização narrativa dos eventos da doença. A narrativa do caso médico, afirma, é central para a epistemologia e prática da medicina; é um constructo desta epistemologia, necessário à investigação racional num domínio onde a experiência subjetiva (e relatos subjetivos daquela experiência por outra pessoa) são os dados básicos e originais da assistência clínica.

A narração médica da história do paciente, tal como a de Sherlock Holmes ao reconstruir um crime, de acordo com a autora, é a incorporação de uma hipótese diagnóstica, isto é, também a reconstrução daquilo que aconteceu de errado. Ela utiliza a apresentação de caso, numa sessão clínica, para referendar essa analogia, dizendo que esta se ordena de acordo com uma conclusão não declarada e prossegue reportando "negações" e detalhes "não percebidos", conduzindo a audiência além das possibilidades que foram descartadas, para centrar o foco nos sinais de uma conclusiva e lógica diagnose. Assim, a experimentação estaria vedada tanto ao 
médico quanto ao detetive, porque a ciência de ambos seria a observação exercitada após o fato.

Hunter, introduz, tal como Epstein (1995), a epistemologia narrativa dos registros/relatos médicos. Ambas ligadas ao campo dos estudos literários, distanciam-se, na articulação entre medicina, literatura e história, da proposta por Carlo Ginzburg (1989), uma vez que, em ambas, o processo de interpretação levado a cabo em todos os três tipos de saberes é hermenêutico.

\section{A semiótica e o discurso médico}

Através da noção de discurso, Ricoeur (1995) demonstra o vínculo entre simbolismo strictu senso e hermenêutica e desta com a questão da verdade que se faz ouvir através dos símbolos, quando se sabe escutá-la. Para ele, o discurso se dá como um evento, simplesmente, porque algo acontece quando alguém fala e essa noção é fundamental quando se considera a passagem de uma lingüística da linguagem ou dos códigos, para a lingüística dos discursos ou mensagens. Se, diz ele, o "sinal" é a unidade básica da linguagem, então a "sentença" é a unidade básica do discurso. E dizer que o discurso é um evento é enunciar, antes de mais nada, que este se realiza temporariamente e no presente, enquanto o sistema de linguagem é virtual e atemporal. Nesse sentido, na proposição de Ricoeur, pode-se dizer que a instância do discurso é auto-referencial, porque este se remete a quem o pronuncia, por meio de uma intrincada rede de indicadores, constituindo-se o evento no fato de que alguém falou, alguém se apossou do discurso ao falar. E, por outro lado, os sinais da linguagem referem-se somente a outros sinais no interior de um mesmo sistema, de tal modo que a linguagem não tem um mundo tanto quanto não tem um tempo e um sujeito; todavia, o discurso dirige-se a um mundo que ele pretende descrever, expressar ou representar.

Já para Ginzburg (1989), o signo (na sua assunção de sinal) dá sempre a conhecer algo mais através da atividade de interpretação. Nesse sentido, indícios, pistas, refugos, detalhes, palavras se abrem para outros sentidos porque comportam conotações, mesmo que, por vezes, diferenciadas. Por exemplo, o termo firasa, extraído do vocabulário sufi, segundo informa, designava não só as intuições místicas quanto as formas de discernimento e sagacidade. E, acresça-se, é utilizada por ele para conotar o órgão do saber indiciário.
Eco (1994), operando na moldura peirciana de signo, diz que as expressões lingüísticas veiculam descrições de fatos e que estes podem tornar-se sinal de outra coisa, via complicados mecanismos de inferência. Chama a atenção para a existência de uma atualização da manifestação linear de um texto que é sempre, frisa, cooperação para fazer dizer ao texto o que, na superfície, ele não enuncia, mas que quer fazer saber ao seu destinatário. Esta cooperação é da ordem do social. Por exemplo, diz ele, só se faz necessário pronunciar Faz frio nessa sala para que essa asserção seja lida como um pedido para se fechar a janela.

Um exemplo análogo ao de Eco pode ser fornecido, tomando por base a análise de um prontuário médico, referente a uma criança portadora da síndrome de Down.

Nele, além dos dados pessoais do paciente (nome, endereço, idade, cor, sexo, nome do pai e da mãe) está contida a história familiar, da gestação, do parto e a da própria criança aliada ao registro dos dados obtidos no seu exame físico, mediante o qual, o diagnóstico de síndrome de Down é estabelecido. O que importa, aqui, é a anotação: firmou a cabeça com $2 m$ (sic!!!). O registro "sic!!!" é o bastante para asseverar ao pesquisador, ou qualquer outro leitor, que a narrativa/texto médico questiona a veracidade das informações prestadas pela mãe. Aliás é ele utilizado precisamente para isso. Não é a sentença "firmou a cabeça com dois meses" que leva para a verdade/mundo do médico - isto é, a "verdade" de estar a mãe esquecida, fantasiando ou mentindo - mas o símbolo "sic" que, no geral, remete, no seio do social, para a idéia de "literal".

$\mathrm{Na}$ semiótica peirciana, o signo pode ser denominado de Ícone, Índice e Símbolo, sendo que este último é descrito como sendo referente ao Objeto que denota, em virtude de uma lei, uma associação de idéias que opera no sentido de fazer com que o símbolo seja interpretado como se referindo àquele objeto. Assim, para Peirce, ele é, em si mesmo, uma lei ou tipo geral, isto é um Lessigno. E esta é uma lei normalmente estabelecida pelo homem, não sendo um objeto singular, porém um tipo geral que será significante (1995).

O "sic!!!" do prontuário funciona, portanto, como um símbolo, uma vez que é simbólico tudo o que permite a interpretação e a efetivação de um sentido indireto, porém não deixa de ser um signo. A linguagem é produtora de sentidos indiretos. O modo simbólico não caracteriza um tipo particular de signo, nem uma modalidade 
específica de produção sígnica; ele assinala apenas uma modalidade de produção ou interpretação textual. Conforme assinala Eco (1994) o modo simbólico pressupõe um processo de "invenção" aplicado a um "reconhecimento".

Como em qualquer outra doença cromossômica, na síndrome de Down, os dados familiares são de fundamental importância à indicação da investigação citogenética, com vistas a esclarecer o cariótipo.

Embora os especialistas estejam acostumados a analisar as dispersões cromossômicas diretamente ao microscópio, por vezes, para melhor sistematizar e pesquisar processos que podem ser responsáveis por determinadas anomalias genéticas, costumam proceder ao recorte dos cromossomos de uma fotomicrografia e arranjá-los em pares segundo uma classificação padronizada, internacionalmente acordada. A figura que se forma é o cariótipo (figura 1), termo também usado para designar o conjunto dos cromossomos de um indivíduo ou de uma espécie (Thompson et al., 1993).

Atualmente, o cariótipo é encarado como integrante obrigatório do processo de diagnose da doença (Cunningham, 1996; Stratford \& Gunn, 1996; Selikowitz, 1997; Pueschel, 1998; Hassold \& Patterson, 1999), apesar deste ser, claramente, na imensa maioria dos casos, feito a partir do exame físico do paciente.

Figura 1

Metáfase com cromossomos

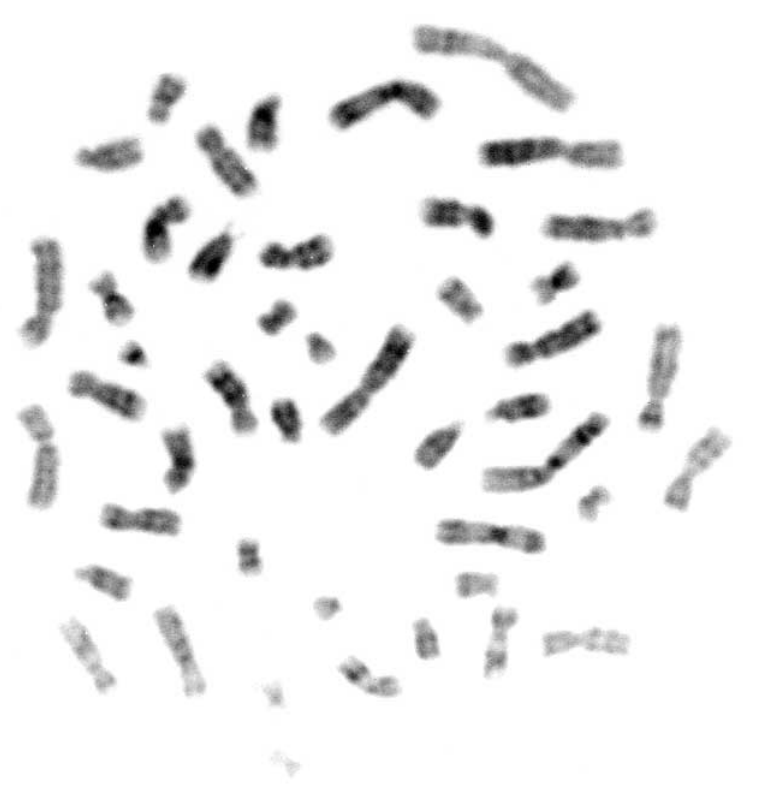

O cariótipo remete também para a idéia de símbolo. Ele envia não só para o emparelhar das características herdadas do pai e mãe, como para a imagem do acasalamento. Nele está pois presente a "teologia" do nascimento, a necessidade do par homem/mulher para a reprodução da espécie. Na célula os cromossomos aparecem, tal como os recursos tecnológicos (cultura celular, técnicas de bandeamento, de hibridização in situ, microscopia eletrônica, fotomicrografia e etc.) os "revelam". Eles compõem um texto onde estão escritos os sinais da hereditariedade e da individualidade. São partes constitutivas da materialidade dos corpos, expressando-se via suas superfícies. Já o ideograma, utilizando uma imagem análoga a do bastão (figura 2), faz "uso" do primeiro texto - os cromossomos como aparecem no cariótipo -, como se cada segmento contivesse toda a verdade, sem contudo, como é óbvio, permitir a qualquer um enunciar o que quiser a seu respeito. $\mathrm{O}$ pensamento da ciência é a autoridade que preside a interpretação e produz o texto, nele buscando a legitimidade de suas assunções. E nesse ponto reencontra-se a proposição de Eco (1994): trata-se de um processo de "invenção" aplicado a um "reconhecimento".

Os dados familiares também são dispostos num diagrama que, em todos os prontuários examinados, precede as anotações referentes aos dados físicos pessoais da criança (peso, altura, perímetro encefálico), a história da gestação, parto e da evolução da doença. É o heredograma composto por símbolos padronizados, onde se tem a utilização de um texto, com base noutro - a história familiar do paciente, no qual, mais uma vez, é a autoridade do especialista quem dita aquilo que ele deve conter e como deve ser lido.

Os "símbolos" representam objetos ou relações abstratas, como as fórmulas lógicas, químicas, algébricas e o diagrama. Se emprega-se a palavra criança, alterando a ordenação das letras que a formam, o termo fica irreconhecível. Mas se ela for escrita ou pronunciada de diferentes modos (escrita em letra de forma ou cursiva, por exemplo, assim como pronunciada de acordo com o acento regional), a variedade das formas de expressão não transforma a compreensão do conteúdo, pelo menos no nível mais elementar de significação. Já com o diagrama as operações encetadas na expressão modificam o conteúdo e, variando de acordo com as regras, o resultado fornece informações novas sobre este. Eles não são naturais, no sentido de 
que contêm elementos de motivação mas, recorrendo-se à semiótica peirciana, icônicos ou analógicos (Eco, 1994). E, de certa forma, é a analogia entre o modelo de conhecimento da história e da medicina que é recuperada nesse diagrama composto por símbolos. É como um reenvio à origem.

Para o historiador a árvore genealógica (figura 3) faz parte da historiografia. A Guerra das Rosas, por exemplo, seria incapaz de ser compreendida sem que as árvores genealógicas, mostrando as relações de parentesco entre os contestantes, tivessem sido registradas, mesmo que com o objetivo único de louvar a realeza. $\mathrm{O}$ estudo histórico da Bíblia, por questões até de ordem teológica, lançou mão da genealogia e de seu traçado esquemático para reconstruir a história das dinastias judaicas, imbricadas à manifestação de Deus na terra.

Nessa antiga tradição de retroagir para os ancestrais mais remotos, como meio a reforçar a historicidade dos homens, a genética humana vai inspirar-se para montar o heredograma, a primeira etapa ao estabelecimento dos padrões de hereditariedade.

Porém, como nos registros históricos, esse diagrama contém uma epistemologia narrativa, tal como a referida por Epstein (1995) ao processo de diagnóstico. Ao olhar-se o heredograma na figura 4 , retirado de um prontuário referente a um paciente atendido no Ambulatório de Síndrome de Down, do Centro de Genética Médica José Carlos Cabral de Almeida, do Departamento de Genética do Instituto Fernandes Figueira, da Fundação Oswado Cruz, uma narrativa se desenrola:

O avô paterno da criança com síndrome de Down morreu, mas sua avó está viva. Por parte de pai ele possui um tio e uma tia. Seus avós maternos estão vivos e ele tem, por parte de mãe, também um tio e uma tia. Seu pai tem 31 anos e sua mãe 27 e ele tem um irmão e duas irmãs. Sua irmã mais velha tem sete anos, a do meio seis e seu irmão, cinco. Sua mãe teve dois abortos espontâneos antes dela nascer e ela, aos nove meses foi diagnosticada como portadora da síndrome de Down.

A mesma história poderia ser contada de outra maneira:

Uma menina de nove meses foi diagnosticada como portadora da sindrome de Down. Suas outras duas irmãs, uma com sete e a outra com seis anos, eram normais, assim como seu irmão de cinco anos. Sua mãe tinha vinte e sete anos e seu pai trinta e um. Sua mãe ficara grávida diversas
Figura 2

Diagrama em bastão representando um cromossomo

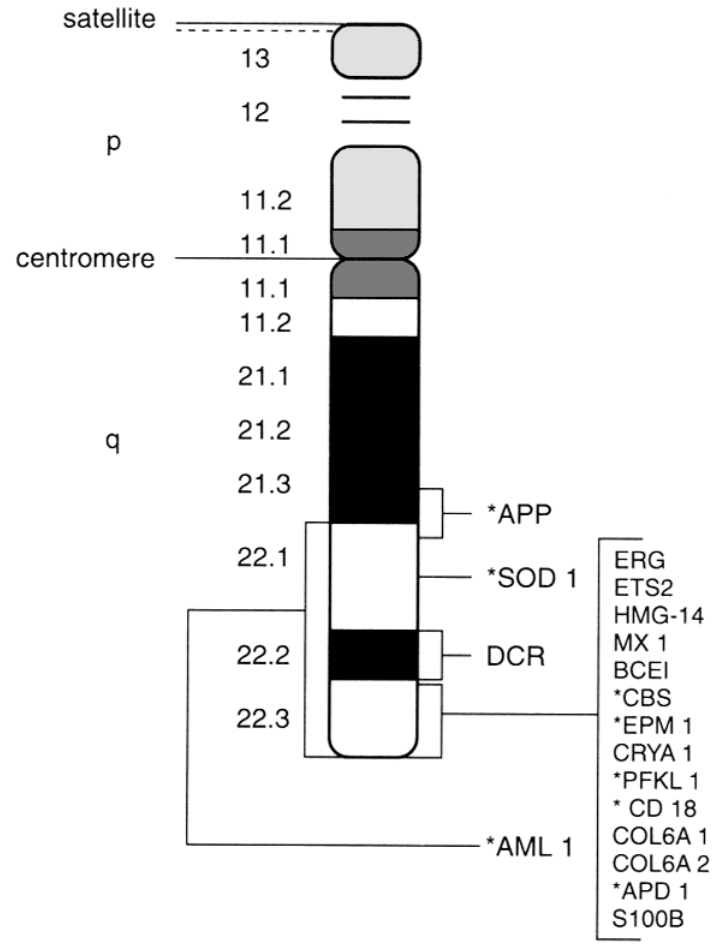

vezes e em intervalos de tempo pequenos, uma vez que até entre ela e seu irmão de cinco anos, engravidara duas vezes, só que perdera espontaneamente os bebês. Ela tinha duas tias e dois tios, uma delas e um deles era por parte da mãe, enquanto os outros dois eram por parte de pai.

Narrativa é uma expressão polissêmica. Todavia, de uma forma geral, pode-se defini-la como a organização de eventos no tempo, elaborando-se ou não relações causais entre tais eventos, normalmente associados a algum tipo de mudança. Nos exemplos acima esta forma de ordenação torna-se clara através não só da descrição das gerações, da idade das pessoas, como também da maneira como a mãe da criança com síndrome de Down reportou ao médico sua experiência de seis gravidezes, sendo que duas delas abortadas espontaneamente. Todos os nascimentos e os dois abortos obviamente associam-se a algum tipo de mudança.

Hunter (1991) expressa muito bem a diferença entre as narrativas do médico e as do pa- 
Figura 3

Árvore genealógica da família de Macabeus

The Maccabean Family

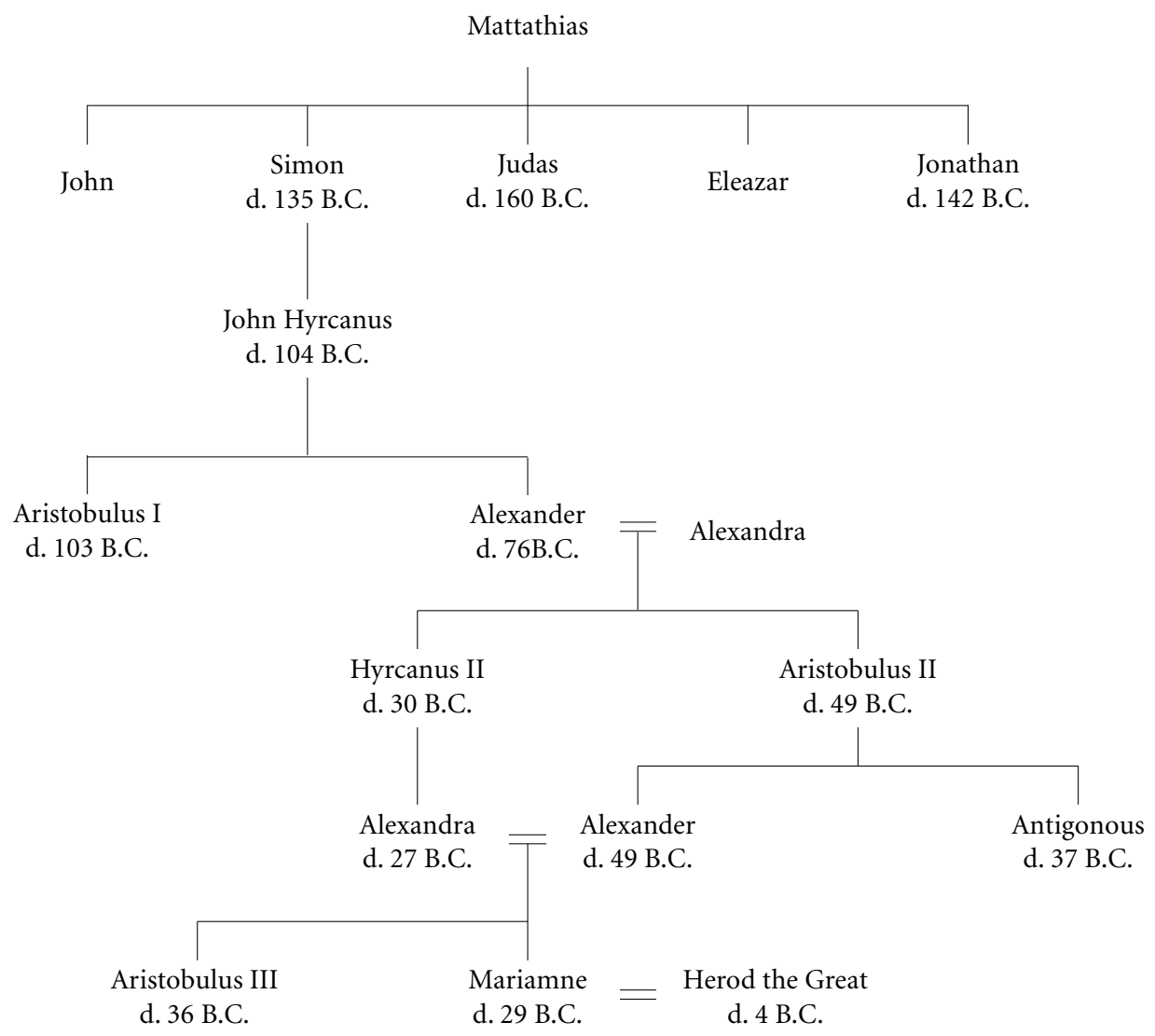

ciente, muito embora ambas se refiram à mesma doença. A história que os pacientes narram é o relato originário e motivado que eles (ou os responsáveis por eles) fazem de suas experiências de adoecimento; a do médico é aquela construída a partir de "recortes" das narrativas que lhes foram apresentadas, salientando as partes da história pessoal e familiar do doente que lhes interessam e, também, a partir dos sinais e sintomas das enfermidades nos corpos. A primeira diz respeito aos efeitos da enfermidade numa vida e é uma cronologia simples, com uma etiologia implícita dos acontecimentos da doença; a segunda pode não ser estritamente cronológica, porém começando com o passado bem próximo, lança-se ao futuro e conta o processo de diagnose.

O prontuário médico, por outro lado, é o depositório desta primeira narrativa médica. É com ba- se nele que os casos médicos são apresentados, quer oralmente ou escritos em revistas especializadas. É nele que se encontra o enredo da doença e do tratamento, cujo autor é basicamente o médico. Nesse texto, imagens, números, gráficos se misturam. Não parece, tanto quanto o heredograma que dele faz parte, constituir-se numa narração, no entanto, neles o ato de narrar é meticuloso, cuidadoso e revelador não só dos fatos físicos, como Hunter (1991) aponta, mas também da inserção social, dos hábitos alimentares, da maneira de carrear as queixas e/ ou sintomas. Ele é minimalista, econômico, mas indubitavelmente individualizado e, por isso, não é um texto atemporal ou supra-histórico. Nele encontram-se dados relativos à moradia, existência ou não de famílias grandes, ocorrên- 
Figura 4

Heredograma representando a família da paciente

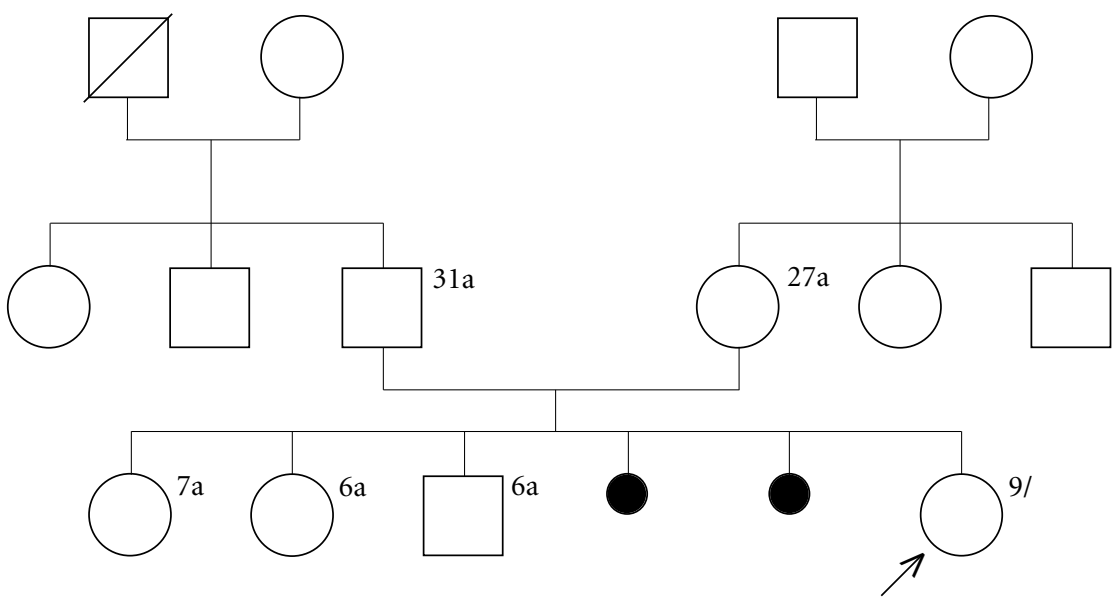

cias na evolução da doença, progressos e retrocessos no desenvolvimento da enfermidade, nascimento, morte. Os fatos são dispostos e dão conta de rupturas e continuidades, estabelecendo relações causais entre umas e outras, nem que seja pelo indício de mudanças de medicação e/ou requisição de novos exames.

Não se pretende afirmar que todos os prontuários são iguais, até porque nem os pacientes, nem os médicos, nem as doenças, nem as instituições e as circunstâncias e finalidades são as mesmas. Todavia, neles a epistemologia narrativa, embutida no processo de diagnose e de tomada de decisão, se exemplifica, mostrando o quanto ela é formadora da prática clínica.

O que se escreve a seguir, sem dúvidas, é uma metanarrativa. Ela é, uma espécie de história fatual, do diagnóstico e da evolução de uma criança com síndrome de Down durante um período que vai de antes de seu nascimento até quase ao final de seu primeiro ano de vida. Esta história construiu-se em cima dos dados de um prontuário (figura 5), sendo os eventos encadeados seguindo a mesma ordenação pela qual foram anotados. A única informação inserida fora da ordem dada pela notificação médica é a da razão da consulta, uma vez que ela estava anexada ao prontuário, mas também contando uma história. Tratava-se de um breve relato de uma neurologista, dando conta do encaminhamento ao Ambulatório de Síndrome de Down. É uma história dos acontecimentos, tingida pelo em- pírico, no qual o ato de narrar não se reporta aos ditames propugnados pelos procedimentos científicos da história, mas nem por isso deixa de ser menos verdadeira.

João nasceu no dia 16 de fevereiro de 1996, pesando $3,350 \mathrm{~kg}$ e medindo $52 \mathrm{~cm}$. Sua mãe havia tido duas filhas antes dele. A mais velha tinha 16 anos e a mais nova 12. Porém sua mãe já havia ficado grávida e tido dois abortos espontâneos. Suas duas irmãs eram filhas do primeiro casamento e ele do segundo. Sua mãe tinha 37 anos e seu pai 28. Os dois haviam se separado logo no início de sua gestação. Sua mãe afirmava que em função disso havia tido sangramento e tivera que tomar Dactil OB. Ela fizera várias vezes o bHCG sempre com resultado negativo. Confirmada a gravidez fez o pré-natal completo. João nasceu a termo e de parto cesáreo. A pediatra que $o$ atendeu, encaminhou-o a uma neuropediatra e esta ao observar um quadro de hipotonia generalizada, presença da prega simiesca palmar e implantação capilar deficiente, encaminhou-o para o Ambulatório de Síndrome de Down, do Departamento de Genética do Instituto Fernandes Figueira requisitando o cariótipo para confirmar o diagnóstico de síndrome de Down.

A primeira consulta de João foi no dia 28 de junho de 1996. O exame revelou presença de epicanto, redundância de pele cervical incluindo a porção anterior do pescoço, prega simiesca e arco tibial plantar. Diante de tais evidências o diagnóstico foi confirmado. Recomendou-se: abertura 
Figura 5

Prontuário
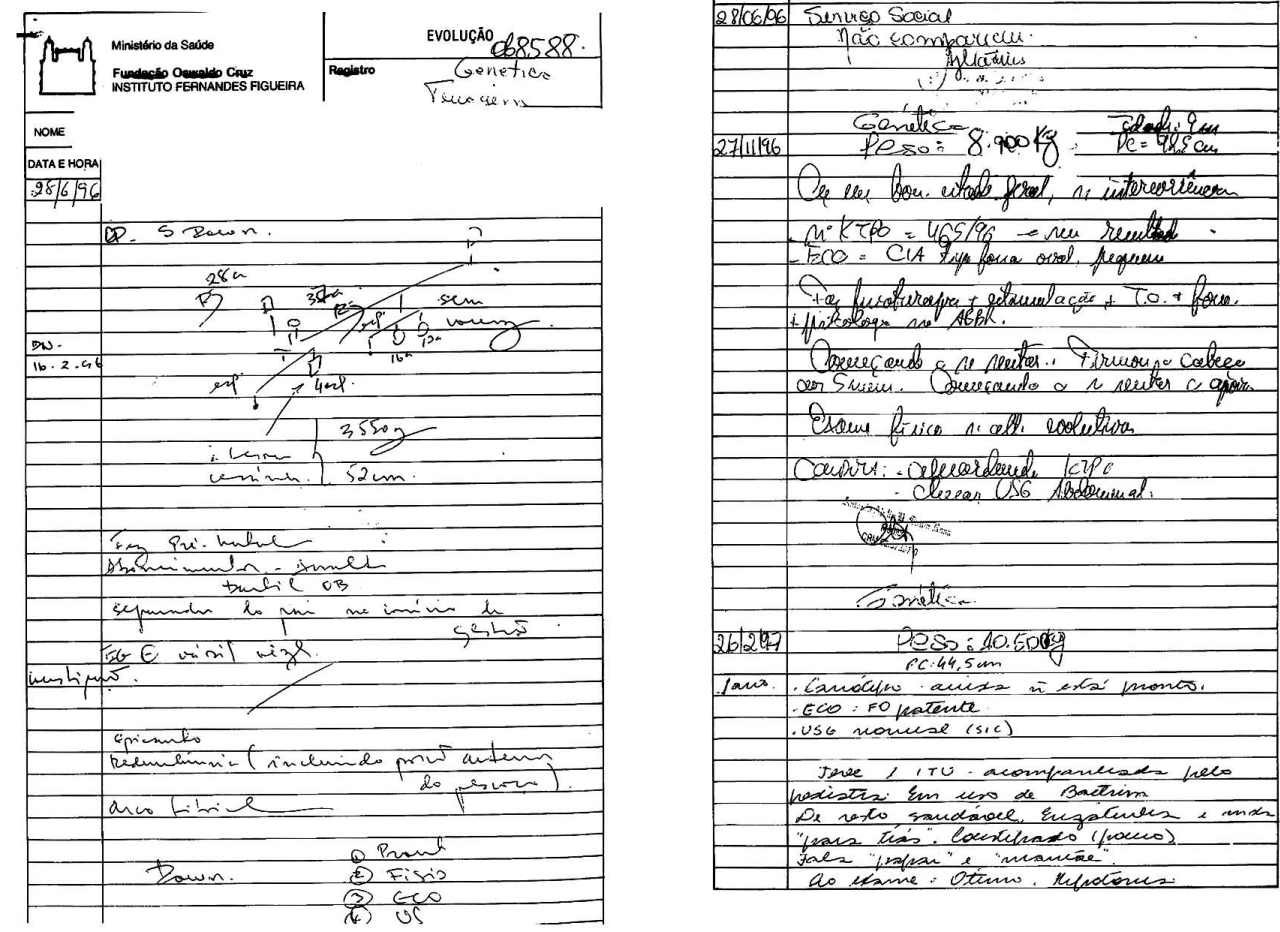

de prontuário para torná-lo usuário do Ambulatório, fisioterapia, estudo ecocardiográfico, ultrasonografia abdominal e, também, a análise do cariótipo.

Ao sair, a mãe de João não o levou até o serviço social, mas retornou com ele à consulta seguinte que havia sido marcada para o dia 27 de novembro. Ele havia aumentado de peso, estava em bom estado geral e o ecocardiograma era compatível com CIA pequena, tipo fossa oval. Ele já estava sendo estimulado, fazendo fisioterapia e fonoaudiologia na ABBR. Estava também sendo acompanhado por uma psicóloga. Já havia firmado a cabeça aos 5 meses e começava a querer sentar. Foi, então, encaminhado para o serviço de cardiologia, reforçando-se a necessidade de ultrasonografia abdominal.

Quando João voltou, passado pouco mais de dois meses, ia fazer um ano. Seu cariótipo ainda não havia ficado pronto. O ecocardiograma confirmou FO patente e a ultra-sonografia foi considerada normal. Durante o intervalo entre as duas consultas havia sofrido uma internação acompanhada pelo pediatra e, atualmente, estava fazen- do uso de Bactrim. De resto, encontrava-se saudável, engatinhava para trás e começava a falar 'papai' e 'mamãe'. Ao exame: ótimo.

Narrou-se o prontuário de João, tendo por base a narração do médico que, por sua vez, embasou-se na narrativa feita pela mãe dele. Apesar de todos os múltiplos níveis narrativos, dos objetivos e visões desiguais de mundo, das formas distintas da narração, os procedimentos médicos, históricos e ficcionais, visualizam e apresentam fenômenos da vida humana. Consubstanciam-se em matrizes de discursos, nas quais o relato caracteriza-se por ser ao mesmo tempo figurativo - porque comporta personagens que levam a cabo ações -, e inscrito dentro de coordenadas espaciais e temporais - predominando a última sobre a primeira (Cardoso, 1997).

\section{Doença e narrativa}

Desde finais da década de 1960 as narrativas de doenças (illness narratives) assumiram papel 
central nos estudos realizados por antropólogos, sociólogos, literatos, médicos, psicanalistas, psiquiatras, enfermeiras, sendo encaradas como caminhos ao entendimento dos esforços dos clientes/pacientes em lidar com suas vidas, sobretudo, face aos problemas de quebra de identidade que as doenças crônicas acarretam.

Kleinman (1988) - a quem se deve a expressão illness narratives - tendo como alicerce a categoria sofrimento e a condição humana, como social e culturalmente edificada, postula a narrativa como a forma pela qual os doentes modelam e dão sentidos aos seus padecimentos. Para este médico, as orientações culturais da coletividade, dentro da qual se vive, organizam o senso comum sobre como entender e cuidar das enfermidades, por isso as experiências de adoecimento são sempre culturalmente moduladas. Segundo ele, o médico, por também sofrer as mesmas influências, pode estabelecer uma relação com o seu paciente, mas ao re-escrever o adoecimento, em termos de teorias da desordem orgânica ou mental, cria a doença; ela é o que ele foi treinado a ver, através das lentes teóricas de sua forma particular de prática. Assim, conclui, o clínico reconfigura os males do paciente e de sua família (illnesses) como assuntos técnicos, isto é, como "entidades" mórbidas (diseases).

Hydén (1997) afirma que o conceito de narrativa primeiro ocupou um espaço periférico no campo do conhecimento sociológico das doenças mas, hoje, ocupa um lugar predominante por permitir captar aspectos nucleares da vivência do adoecimento em seus contextos sociais específicos. Nesse sentido, os trabalhos desenvolvidos de dez anos para cá sofreram mudanças temáticas, teóricas e metodológicas. A transformação temática liga-se ao deslocamento da narrativa como meio de estudo das práticas médicas, para fio condutor da análise das experiências do sofrimento dos doentes; a virada teórica reporta-se à possibilidade de estudar a realidade da doença à parte das concepções e definições do discurso biomédico e, por fim, a modificação metodológica remete-se à consciência de que fatores situacionais influenciam as narrativas e que continuamente novas narrativas são produzidas pela mesma pessoa, dependendo de novos contextos.

Revisando todos os trabalhos já realizados, esse sociólogo ligado ao estudo das enfermidades e daqueles por elas acometidas, tendo por fio condutor a narrativa de doenças, acaba propondo três tipos de narrativas, fundamentados em seus aspectos formais, ou seja, nas relações entre narrador, narrativa e doença. São eles: "doença como narrativa" - narrador, doença e narrativa combinam-se numa só pessoa, no caso, portanto, as narrativas que os pacientes fazem a seu médico; "narrativas sobre doença" uma narrativa que traz em si conhecimentos e idéias sobre as doenças, nesse sentido, as que os médicos fazem de seus pacientes, entretanto, nada impedindo que os doentes também as façam, misturando-as, em determinados pontos, com àquelas do primeiro tipo e, por fim, "narrativa como doença”, significando situações nas quais uma doença gera distúrbios na narração, como no caso descrito por Oliver Sacks de um paciente que desenvolveu síndrome de Korsakow e, em conseqüência, perdeu sua capacidade de narrar.

Os trabalhos de Kleinman (1988) e Hydén (1997) se diferenciam, não só em função da auto-imagem/formação, como também por seus objetivos. O primeiro, após estabelecer uma rede analítica de acesso aos sentidos das doenças e narrar as experiências de adoecimento de seus pacientes, volta-se para a proposição de um guia aplicável à assistência aos pacientes, visando alterar a educação e treinamento médicos. $\mathrm{O}$ segundo, descrevendo e analisando as mais diferenciadas propostas, tem por escopo fornecer uma abordagem teórica e metodológica dos estudos sobre doença. Enquanto um parte do determinismo sociocultural moldando os discursos médicos e leigos, o outro, das bases epistemológicas da sociologia, para estatuir as narrativas de doença como produtos sociais e culturais, como uma transformação e expressão do sofrimento dos corpos e, sobretudo, como a tentativa das pessoas que sofrem de construírem um novo contexto para suas vidas.

Arthur Frank (1995), outro sociólogo, tendo por base os teóricos da pós-modernidade e sua própria experiência com a doença, propõe que o "contador de histórias ferido" (wounded storyteller) fala não sobre seu corpo doente, mas através dele. A doença crônica estabelece o caos e o doente perde sua bússola. A narrativa personalizada, não mais "meta”, ajuda-o a reencontrar o caminho e o torna participativo, integrante e conhecedor do próprio adoecimento.

Baseado na sociologia weberiana, ele propõe quatro tipos ideais de corpos em sua relação com o adoecer, esclarecendo que esse é um meio conceitual e reflexivo, uma linguagem para falar sobre o que é particular, porque, na realidade, cada corpo individualizado representa misturas distintas de tipo ideais (Frank, 1995). Dependendo do tipo, disciplinado (aquele que 
se define em ações de auto-regimentação), espelhado (o que se explicita em atos de consumação), dominador (auto-identificado na força) e comunicativo (aceita a contingência, associa-se consigo mesmo e existe para o outro: é mensagem), variadas formas de narrativas se formam. Para Frank, corpos desiguais possuem, como ele próprio coloca entre aspas, "afinidades eletivas" com distintas formas de narrativa, sendo que tais afinidades não são determinantes, uma vez que os corpos se realizam, criam-se, nas histórias que contam.

Não há, portanto, apesar da noção que o ideal-tipo carreia, descontextualização, imobilidade e transcendência. No trabalho de Frank, devido à sua própria experiência com o câncer, os corpos precisam de vozes e delas se utilizam produzindo inúmeras narrativas que mudam, assim como também são passíveis de transformarem-se as relações do corpo doente com a doença. Os três tipos de linhas narrativas que identifica são: restituição (o retorno da saúde), caos (negação de qualquer expectativa de melhora) e conquista (a doença é motivo de uma jornada que se transforma numa conquista, se não da saúde, da própria identidade). Todavia, pode-se dar razão a Hydén (1997), quando, ao comentar a tipologia de Frank, aponta que parte de seu problema reside no fato de se basear num cenário limitado de gêneros narrativos, como "caos" e numa meta-narrativa da doença: do "caos" à "conquista".

Morris (1998), ex-professor de inglês e atualmente voltado somente para suas atividades de escritor, pugna por uma noção de doença que seja biocultural. Ele segue a concepção teórica pós-modernista de Lyotard, no mesmo molde de Frank (1995), preocupando-se em sugerir a narrativa como instrumento ético de discussão dos rumos tomados pela biotecnologia, assim como meio de romper o silêncio imposto ao doente pelo sofrimento.

Como a maioria dos autores desde Kleinman, o progresso das tecnobiociências sombreia todo o pensamento de Morris. É o avanço delas que traz à tona a preocupação com a cronicidade, visto que considera os episódios agudos de sofrimento causados por doenças de etiologia virótica ou bacteriana como já superados, não só por meio da melhoria das condições de saneamento, como pela existência das vacinas e da antibioticoterapia. Tais episódios jamais são vistos como rupturas, uma vez que a recomposição da saúde se dá e eles acabam por serem esquecidos, não acarretando uma experiência continuada de padecimento. É evidente que dores causadas, por exemplo, por uma cefaléia renitente, por uma hérnia cervical ou lombar ou pela depressão, são consideradas no espectro da permanência, mas sua presença é amenizada em função de não carrearem a idéia da morte. É, pois, dos esforços para ampliar a vida que estes autores falam. Sendo que normalmente esta ampliação se dá via o afastamento da morte, e não através da reflexão acerca das técnicas de visualização e individuação do feto que prolongam, de forma virtual, a linha da vida do ser na história para antes do nascimento.

Por sua vez, Anne Hunsaker Hawkins (1993) encara as narrativas de doença sob a perspectiva de gênero literário. Seu trabalho conduz o leitor pelo que ela chama de patografias e, sobretudo, pelos mitos que as embasam. A História das Idéias se faz presente, embora encarada sob uma perspectiva interdisciplinar com o estudo do campo literário em senso estrito. Para a autora três tipos de argumentação narrativa estão presentes nesse tipo de literatura: a "didática”, baseada numa experiência vivida que é passada aos outros, no sentido de infundir-lhes confiança e esperança; a "raivosa" (angry), que se volta contra a dor que as técnicas médicas invasivas produzem nos corpos, sem, contudo, atacar a figura do médico e, finalmente, o que chama de "saudável-mentalidade" (healthymindedness), termo que toma emprestado a William James, para caracterizar aquelas que enfatizam a fé religiosa, o poder curativo da natureza e o envolvimento ativo do paciente em todos os aspectos de seu tratamento. Esse último tipo, inclusive, tenderia a se articular à medicina alternativa mais em função de suas ênfases do que em função de um descontentamento, puro e simples, com a medicina ortodoxa.

A importância da narrativa na medicina, diante do seu caráter marcante de "ciência de indivíduos" como a chama Hunter (1991), não se reporta só às formas de escuta necessárias ao exercício da cura ou da melhoria das condições de vida dos doentes, mas é parte epistemológica da construção de um saber que se faz na prática, sem abrir mão, entretanto, da razão científica, criando hipóteses/abduções que articuladas ao raciocínio dedutivo, necessário para determinar o que deve ser, avança na aquisição de conhecimentos. Todavia, Kleinman, Hydén, Frank, Morris e Hawkins, em que pesem as diferenças de abordagem, têm razão ao focar a dimensão da inter-relação comunicacional, pois é esta que cada dia mais tende a se restringir, di- 
ante de uma biomedicina que educa os médicos a se distanciar do sofrimento como forma sine qua non de neutralidade eficaz, ao mesmo tempo que enfatiza os meios sofisticados de diagnose, oferecendo-os como instrumentos infalíveis de estabelecimento da verdade do que ocorre de errado na mais ínfima partícula interiorizada dos corpos. Juntos, médicos e pacientes estão imersos no mercado hipercapitalista das trocas e das estratégias flexibilizadas de acumulação (Haraway, 1997), dependentes de velozes manipulações de poder, do discurso sobre aquilo que seus genes são capazes de determinar, da contingência do que vão expressar, submetidos também a seus inconscientes e às rápidas e incessantes transformações socioculturais (Castiel, 1999).

\section{Sempre narrando histórias}

No que diz respeito à prática da escrita da história, fundamentada no ideal da objetividade da narrativa, dever-se-ia fazer uma escrupulosa reconstituição dos fatos que, depois de testados e ordenados, comporiam um relato cronológico. Seu estatuto de ciência derivaria do estudo crítico de fontes oficiais, com vistas ao estabelecimento de sua veracidade. Essa era a ponta visível do pressuposto positivista de que era possível captar o passado, tal ele o fora, a partir da exatidão dos fatos e da absoluta confiabilidade das fontes. A ênfase nesse modelo e sua correlação com a narrativa levaram, a partir do esgotamento exclusivo do paradigma mecanicista, ao afastamento progressivo da temática da narrativa. Stone (1991) tem razão ao afirmar que os historiadores sempre contaram "estórias", mas que a história dos grandes acontecimentos acabou desqualificando a importância da narrativa para o ofício do historiógrafo.

Depois de Hiroshima e Nagasaki, o mito do progresso ocidental passou a ser questionado, processando-se uma rachadura na ideologia herdada do iluminismo, apontando uma paulatina modificação na maneira de se pensar a ciência. Nesse contexto, a reabilitação da narrativa, com o desenvolvimento das pesquisas na área da história sociocultural, representa menos uma volta a um estilo de escrita predominante no século 19 e mais uma preocupação com o cotidiano da vida, com o sofrimento e com a dor experimentada pelos seres humanos comuns. Ora, essa reabilitação também passa a se consubstanciar nos trabalhos não só de médicos - veja-se Kleinman e Sacks, dentre outros -, mas igualmente nos esforços da antropologia, da sociologia e da crítica literária - Frank, Morris, Epstein, Hunter, Hawkins, para ficar com os já citados - voltados à complexidade com que se revestiu a medicina na atualidade.

Aproximar-se da noção de narrativa como uma forma, entre outras, de manifestação do pensamento e de sua comunicação entre os seres humanos, é entendê-la, não como um desvio ou deformação do narrado, mas como extensão dos códigos de uma cultura que dota a realidade da possibilidade de ser narrada. É com a linguagem que se dá a ordem e é através dela que o homem se depara com uma multiplicidade de maneiras de ordenação.

A possibilidade de uma semiótica narrativa depende de se separar um nível aparente das narrações - no qual as significações dão a impressão de depender da marca - e um nível mais profundo cuja consideração faria perceber uma "narratividade" comum e mais geral. Desse modo, as estruturas narrativas - o tronco submerso - são anteriores às suas manifestações nas histórias contadas (Cardoso, 1997).

Por proceder dessa maneira é que Laqueur (1992), trabalhando os relatórios de autópsia, na sua forma moderna, e a novela, mostra que ambos desenvolveram-se na mesma época e empregaram estruturas narrativas, operando ao longo do axioma causa e efeito para prescrever determinadas ações preventivas dos "males". Por isso ele chama os dois tipos de escritos de "narrativas humanitárias" (humanitarian narratives), apontando que serviam ao propósito de conclamar à compaixão pelos corpos sofredores, tornando-a um imperativo moral impulsionador da ação comunitária.

A historiografia e o relato do caso médico também compartilham, com a escrita imaginativa, uma herança comum de retórica. Tal como os historiadores, os médicos registram a história do paciente a partir de conjeturas qualificadas e iluminadas pela formação profissional, baseando-se numa seleção de inúmeros eventos e de evidências fornecidas por fontes diversas - exames complementares, literatura médica, pesquisas epidemiológicas, dentre outras. As relações causais são freqüentemente invertidas como, por exemplo, o sentido de um acontecimento ou sintoma sendo definido pela seqüela que deixou. Nesse caso, os efeitos guiam para as etiologias ou para o prenúncio de prognósticos mais do que os episódios originais levam ao diagnóstico. O movimento, tal como na 
história, é do presente para o passado e deste para o futuro.

Ao exercitarem a função de produzir histórias, tanto o historiador como o médico, assumem a narrativa como uma modalidade de escrita sobre a história, incluindo aí, os elementos imaginários que penetram qualquer narração. Isto, pelo contrário, não implica dizer que história e medicina são a mesma coisa e que ambas são ficção, mas tão somente que, se nas duas há a construção de um enredo, porque relacionam elementos dispersos e ligam eventos e/ou acontecimentos isolados, elas assim o fazem de forma constrangida, construindo sua objetividade que é permanentemente confrontada e reformulada por novas e complexas interações biológicas, culturais, sociais, ecológicas... A criatividade é fundamental a qualquer posicionamento que se pretenda científico e os cientistas não têm como predicado estar a serviço da verdade, portanto não a traem. Todavia, o seu problema é com a história. E a verdade, no fundo, é aquilo que a história faz (Stengers, 1997).

A historiografia da história e a história da medicina demonstram que ambas buscam o argumento mais forte e o mais persuasivo, porém nunca vão encontrar o derradeiro. A objetividade não lhes é dada, mas sempre construída e (re)construída, pela confrontação dos testemunhos que arrolam. O arbítrio do historia- dor e do médico não se confunde com o ato de vontade que cria a ficção. História e medicina estão em aberto, sempre passíveis de revisões. $\mathrm{E}$ quem encaminha estas revisões são homens/ mulheres, médicos(as) e historiadores(as), que examinam, interpretam, julgam, argumentam, através de diferenciados métodos, teorias e categorias. Entretanto, espera-se, com modéstia, isto é, sem a desmesura de quem pretende pronunciar a palavra final, que a todos os demais silencia em nome da verdade total e absoluta.

José Américo Pessanha (1988), ao discutir o caráter não ficcional da história, porém pontuando seu conteúdo narrativo, diz: Porque de fato existiu, Napoleão se distingue de James Bond. Mas, o historiador que escreve sobre ele, organizando e relacionando informações, interligando “instantâneos", montando seqüências e elos causais, inevitavelmente cria, imagina, fabula: é narrador.

Os relatos históricos, tal como os médicos, não podem depender somente de seus supostos conteúdos fatuais, pois as explicações que os homens produzem sobre si, os outros e as coisas são, na maioria das vezes, mais determinadas pelo que deixam de fora do que por aquilo que nelas sobressai. E acresça-se, influenciadas pela auto-imagem que cada um faz de si; pela exigência de procurar por um sentido, portanto da "fábula" como forma de criação. 


\section{Referências bibliográficas}

Cardoso MHCA 2000. A herança arcaica de um modelo: história, medicina... e a síndrome de Down. Tese de doutorado. Instituto Fernandes Figueira, Fundação Oswaldo Cruz, 138pp.

Cardoso CF 1997. Narrativa, sentido, história. Editora Papirus, Campinas, 283pp.

Castiel LD 1999. A medida do possível... Saúde, risco e tecnobiociências. Editora Contra Capa-Editora Fiocruz, Rio de Janeiro, 204pp.

Cunningham C 1996. Understanding Down syndrome. An introduction for parents. Brookline Books, Cambridge, 248pp.

Eco U 1994. Signo. Enciclopédia Einaudi-vol. 31. Imprensa Nacional-Editora Casa da Moeda, Lisboa, 277pp.

Epstein J 1995. Altereded conditions: disease, medicine and storyteller. Routledge, Nova York-Londres, 375pp.

Frank A 1995. The wounded storyteller. Body, illness and ethics. The University of Chicago Press, Chicago, 214pp.

Ginzburg C 1989. Mitos, emblemas e sinais. Morfologia e história. Editora Companhia das Letras, São Paulo, 288pp.

Ginzburg C 1991. Chaves do mistério: Morelli, Freud e Sherlock Homes, pp. 90-129. In U Eco \& T Sebeok (orgs.). O signo de três. Editora Perspectiva, São Paulo.

Haraway D 1997. Modest_Witness@second_millenium. FemaleMan $₫$ _Meets_OncoMouse ${ }^{a}$. Feminism and techonoscience. Routledge, Nova York-Londres, 375pp.

Hassold TJ 1999. The incidence and origin of human trisomies, pp. 67-78. In TJ Hassold \& D Patterson (eds.) Down syndrome. A promising future together. Routledge, Nova York-Londres.

Hawkins AH 1993. Reconstruting illness. Studies in pathography. Purdue University Press, Indiana, 241pp.

Hunter KM 1991. Doctor's stories. The narrative structure of medical knowledge. Princenton University Press, Princenton, 283pp.

Hydén L 1997. Illness and narrative. Sociology of Health and Illness 19(1):49-64.

Kleinman A 1988. The illness narratives. Suffering, healing \& the human condition. Basic Book, Nova York, 304pp.

Langer WL (ed.) 1972. An Encyclopedia of World History. Ancient, Medieval and Modern. Chronologicaly Arranged. Houghton Mifflin Company, Boston.
Laqueur TW 1992. Corpos, detalhes e narrativa humanitária, pp. 239-277. In L Hunter (org.). A nova história cultural. Martins Fontes Editora, São Paulo.

Le Goff J 1984. Apresentação, pp. 7-8. In J Le Goff (org.). As doenças têm história. Editora Terramar, Lisboa.

Morris DB 1998. Illness and culture in the Postmodern Age. The University of California Press, Los Angeles, 345pp.

Moulin AM 1991. Os frutos da ciência, pp. 92-105. In J Le Goff (org.). As doenças têm história. Editora Terramar, Lisboa.

Pessanha JAM 1988. História e ficção: o sono e a vigília, pp. 282-301. In DC Riedel (org.). Narrativa, ficção e história. Imago Editora, Rio de Janeiro.

Porter R 1997. The greatest benefit of mankind.. A medical history of humanity. W. W. Northon \& Company, Nova York-Londres, 800pp.

Pueschel S 1998. Síndrome de Down. Guia para pais e educadores. Editora Papirus, São Paulo, 313pp.

Ricoeur P 1988. Time and narrative. The University of Chicago Press, Chicago, 353pp.

Ricoeur P 1995. Studies in the theory of interpretation, pp. 131-193. In JB Thompson (ed.). Hermeneutics \& the human sciences. The University of Cambridge Press, Cambridge.

Selikowitz M 1997. Down syndrome. The facts. Oxford University Press, Nova York, 192pp.

Stengers I 1997. Power and inventions. Situating sciences. The University of Minnesota Press, Minnesota, 269pp.

Stone L 1991. O ressurgimento da velha narrativa. Reflexões sobre uma nova velha história. Revista de História da Universidade de Campinas 2(3):13-46.

Stratford B \& Gunn P (eds.) 1996. New approaches to Down syndrome. Cassel, Nova York, 487pp.

Thompson MW, Mcinnes RR \& Huntigton, FW 1993. Thompson \& Thompson. Genética médica. Editora Guanabara Coogan, Rio de Janeiro, 351pp.

Zaremba J, 1996. Medical aspects, pp. 73-83. In: B Stratford \& P Gunn (eds.). New approaches to Down syndrome. Cassel, Nova York.

Artigo apresentado em 9/7/2002

Versão final apresentada em 11/9/2002

Aprovado em 15/9/2002 